University of Wollongong

Research Online

Faculty of Engineering and Information

Faculty of Engineering and Information

Sciences - Papers: Part B

Sciences

2018

Knowledge Sharing in Digital Learning Communities: A Comparative Review of Issues between Education and Industry

Timothy Jackson

University of Wollongong, tj889@uowmail.edu.au

Sasha Nikolic

University of Wollongong, sasha@uow.edu.au

Jun Shen

University of Wollongong, jshen@uow.edu.au

Glen Xia

Westpac Bank, glenxia@optusnet.com.au

Follow this and additional works at: https://ro.uow.edu.au/eispapers1

Part of the Engineering Commons, and the Science and Technology Studies Commons

Research Online is the open access institutional repository for the University of Wollongong. For further information contact the UOW Library: research-pubs@uow.edu.au 


\title{
Knowledge Sharing in Digital Learning Communities: A Comparative Review of Issues between Education and Industry
}

\author{
Abstract \\ Digital learning communities have become a focal point of organizational development. The education \\ industry has begun to follow suit by using the same technologies to enhance the learning process \\ through a deeper process of participation. These technological tools complement sound learning design \\ to bring a wealth of benefits to students. These benefits are not without peril. New technological tools \\ shift common issues of education into online environments. This article reviews recent implementations \\ of digital communities and highlights their influencing factors. The factors are then connected to existing \\ factors in knowledge management literature. The key factors found are A) Student interaction with the \\ community, B) Interaction vs grades and C) Student experiences.

\section{Disciplines} \\ Engineering | Science and Technology Studies

\section{Publication Details} \\ Jackson, T. M., Nikolic, S., Shen, J. \& Xia, G. (2018). Knowledge Sharing in Digital Learning Communities: A \\ Comparative Review of Issues between Education and Industry. 2018 IEEE International Conference on \\ Teaching, Assessment, and Learning for Engineering (TALE) (pp. 783-787). United States: IEEE.
}




\section{Knowledge Sharing in Digital Learning Communities: A Comparative Review of Issues between Education and Industry}

\author{
T.M. Jackson \\ University of Wollongong \\ Wollongong, Australia \\ tj889@uowmail.edu.au \\ Jun Shen \\ University of Wollongong \\ Wollongong Australia \\ jshen@uow.edu.au
}

\author{
Sasha Nikolic \\ University of Wollongong \\ Wollongong, Australia \\ sasha@uow.edu.au \\ Glen Xia \\ Group Technology \\ Westpac Bank \\ glenxia@optusnet.com.au
}

\begin{abstract}
Digital learning communities have become a focal point of organizational development. The education industry has begun to follow suit by using the same technologies to enhance the learning process through a deeper process of participation. These technological tools complement sound learning design to bring a wealth of benefits to students. These benefits are not without peril. New technological tools shift common issues of education into online environments. This article reviews recent implementations of digital communities and highlights their influencing factors. The factors are then connected to existing factors in knowledge management literature. The key factors found are A) Student interaction with the community, B) Interaction vs grades and C) Student experiences.
\end{abstract}

Keywords-Knowledge sharing, communities, education, technology, review.

\section{INTRODUCTION}

Inter-student learning can be empowered through the application of technology [1]. Technologies are used to create knowledge sharing communities that are unified by their common cause [2]. Participants are not categorised by nationality, location or time. It is the shared endeavour that binds the group. Student-focused communities have reaped numerous benefits while being exposed to a variety of weaknesses. Research on knowledge sharing communities, in the context of organisational learning, has provided extensive insights about these issues [3]. This paper provides linkages to knowledge management literature by comparing issues collected from a baseline of education case studies. This leads us to the research question: What issues exist in both knowledge management literature and education case studies?

The wide spread availability of technology has attributed to its growing use in the education industry. Traditional face-to-face instruction is now being supplemented or completely replaced in the educational experience [4]. These technologies can support any aspect of the teaching experience from content delivery to project presentations. A key aspect of these technologies is the ability of students to interact with each other to discuss content and compare notes.

When examining the effectiveness of a given technology there are a range of performance indicators. These indicators can be summarised into two categories. The first category is the explicit returns on the technology, that being the grades achieved by the students and how they compare with traditional learning design [5]. This is normally measured in the grades achieved, student pass rates and/or student dropout rates. The other category is the tacit side, which is the difficult process of measuring how much knowledge retained by the student and their experience in the course [6]. This is measured by student motivation, feedback, interest and satisfaction with the course.

The aim of this study is to collect influencing factors of digital learning communities and find comparisons in the knowledge management literature. This study is to benefit the application of technologies that promote inter-student learning by comparing common factors with those in industry.

\section{MeThODOLOGY}

To compare the underlining factors of digital communities with existing knowledge management literature, we needed a baseline from previous education research. To find this baseline, a systematic literature review was used to focus the research and define its limits [7]. The necessary thorough planning is a guarantee to follow a clear direction on how to proceed through the literature search [8]. This was achieved by collecting a pool of relevant case studies in the area and cross checking their underlining factors to discover trends and key features. This method can be broken down into its three stages: 1) search, 2) selection and 3) systematic analysis. 
In the search phase, popular and relevant international databases were examined to provide a reliable cross-section of the literature. The databases chosen were Emerald Insight, Science Direct and IEEE Xplore. These databases provided a range of scientific journals and allowed for a large target pool. With the databases chosen, search keywords were needed that summarized the focus of this paper and those that would narrow the hunt for useful case studies. To describe how a digital community might exist in the literature the following keywords were used: "communities", "informal" "learning", "education" and "technology". Initial searches using knowledge management terminology returned limited results as the education industry rarely used terms such as 'knowledge management system', 'communities of practice' or 'organizational learning'. The final terms chosen were found to be the most basic and direct terms that adequately described what we were looking for.

The selection phase required a smaller assortment criterion to compare the studies. Firstly, the data range was limited to only include the most recent studies available from 2014 to the present. The next criteria were primary case studies that dealt with digital communities directly. This was found to be the easiest way to get first hand data on the issues involved. The final criteria were the context of the education industry. This was used to eliminate any study with a company emphasis and narrow the field to just studies that focused on students. The last filters of this phase were year "2014-2018", type "case study" and industry "education". "Case study" is not a reference to it being labelled a case study but the structure of the research done.

The third and final phase of the methodology was the systematic analysis of the literature. Each chosen case study was analysed for its issues and results. These issues were collected into a detailed factor matrix. From this matrix, issues were grouped into overarching themes. This was done to simplify the comparison of underlining issues with the knowledge management literature.

\section{RESULTS}

The initial search of the international databases identified 21417 articles. Give the vast return, the second phase of the literature discovery was implemented. The year filter "20142018" was used to cut this number down to 6910 articles. Following this the type "case study" lowered this number again to 249 and from these, 11 were found in the industry "education". A more detailed breakdown of the origin of the articles can be found in table 2 and a list of the found articles can be found in table 3 . These articles were analysed based on their relevance to the topic and, more importantly, what factors they discovered in their respective cases. These factors were placed into a factor matrix to visualise correlations. These commonalities were grouped into the following headings: 1) student interaction with the community, the 2) interaction vs student grades, the 3) student experience.

TABLE I. SEARCH FIELDS AND FILTERS

\begin{tabular}{|l|l|}
\hline \multicolumn{1}{|c|}{ Search fields } & \multicolumn{1}{c|}{ Search filters } \\
\hline Emerald Insight: abstract, keywords & communities \\
\hline IEEE Xplore: document title, abstract & learning \\
\hline Science Direct: abstract, title, keywords & informal \\
\hline & education \\
\hline & technology \\
\hline & year (2014-2018) \\
\hline & type (case studies) \\
\hline & industry (education) \\
\hline
\end{tabular}

TABLE II. NUMBER OF ARTICLES FOUND ON INTERNATIONAL DATABASES

\begin{tabular}{|l|r|r|r|r|}
\hline $\begin{array}{c}\text { Search } \\
\text { parameters }\end{array}$ & $\begin{array}{c}\text { Emerald } \\
\text { Insight }\end{array}$ & $\begin{array}{c}\text { Science } \\
\text { Direct }\end{array}$ & $\begin{array}{c}\text { IEEE } \\
\text { Xplore }\end{array}$ & TOTAL \\
\hline $\begin{array}{l}\text { Initial } \\
\text { search }\end{array}$ & 8957 & 11293 & 1167 & 21417 \\
\hline $\begin{array}{l}\text { Year (2014 } \\
\text {-2018) }\end{array}$ & 2697 & 3966 & 247 & 6910 \\
\hline $\begin{array}{l}\text { Case } \\
\text { studies }\end{array}$ & 37 & 4 & 208 & 249 \\
\hline $\begin{array}{l}\text { Education } \\
\text { industry }\end{array}$ & 2 & 1 & 8 & 11 \\
\hline TOTAL & 11693 & 15264 & 1630 & 28587 \\
\hline
\end{tabular}

TABLE III. ARTICLES TO BE DISCUSSED

\begin{tabular}{|l|l|c|}
\hline Authors & Title of the article & Year \\
\hline Conde et al [9] & $\begin{array}{l}\text { Exploring software engineering } \\
\text { subject by using visual learning } \\
\text { analytics techniques }\end{array}$ & 2015 \\
\hline Cheng et al [10] & $\begin{array}{l}\text { 5E mobile inquiry learning } \\
\text { approach for enhancing learning } \\
\text { motivation and scientific inquiry } \\
\text { ability of university students }\end{array}$ & 2016 \\
\hline Gewerc et al [11] & $\begin{array}{l}\text { Academic social networks and } \\
\text { learning analytics to explore self- } \\
\text { regulated learning a case study }\end{array}$ & 2016 \\
\hline Lee et al [12] & $\begin{array}{l}\text { Enhancing project-based learning } \\
\text { through student and industry } \\
\text { engagement in a video-augmented } \\
\text { 3D virtual trade fair }\end{array}$ & 2016 \\
\hline Morillas et al [13] & $\begin{array}{l}\text { Can gamification improve the } \\
\text { benefits of student response } \\
\text { systems in learning? An } \\
\text { experimental study }\end{array}$ & 2016 \\
\hline $\begin{array}{l}\text { Multi-role project (MRP) A new } \\
\text { project-based learning method for } \\
\text { STEM }\end{array}$ & $\begin{array}{l}\text { Learning communities in social } \\
\text { networks and their relationships } \\
\text { with the MOOCs }\end{array}$ & 2017 \\
\hline Warin et al [14] & $\begin{array}{l}\text { Eentio et al } \\
\text { [15] }\end{array}$ & \\
\hline
\end{tabular}




\begin{tabular}{|l|l|c|}
\hline Encalada et al [16] & $\begin{array}{l}\text { Social cloud for information } \\
\text { technology skills an experience } \\
\text { with universities in Ecuador }\end{array}$ & 2017 \\
\hline Rambocas et al [17] & $\begin{array}{l}\text { Teaching business management to } \\
\text { engineers the impact of interactive } \\
\text { lectures }\end{array}$ & 2017 \\
\hline Rodriguez et al [18] & $\begin{array}{l}\text { Study of motivation of engineering } \\
\text { students on multinational design } \\
\text { projects }\end{array}$ & 2017 \\
\hline Rajab K.D. [19] & $\begin{array}{l}\text { The effectiveness and potential of } \\
\text { e-learning in war zones An } \\
\text { empirical comparison of face-to- } \\
\text { face and online education in Saudi } \\
\text { Arabia }\end{array}$ & 2018 \\
\hline
\end{tabular}

TABLE IV. FACTOR MATRIX

\begin{tabular}{|c|c|c|c|c|c|c|c|c|c|c|c|}
\hline & \multicolumn{11}{|c|}{ Authors } \\
\hline Factors & $\begin{array}{l}\sigma \\
\sigma \\
\tilde{\sigma} \\
\tilde{0} \\
0 \\
\tilde{0} \\
0 \\
0\end{array}$ & 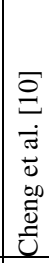 & $\begin{array}{l}\Xi \\
\Xi \\
\dot{\sigma} \\
0 \\
0 \\
0 \\
0 \\
0 \\
0 \\
0\end{array}$ & 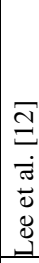 & 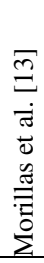 & 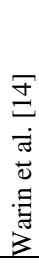 & 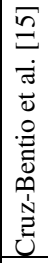 & 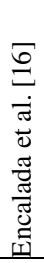 & 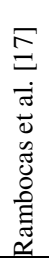 & 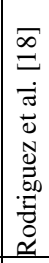 & 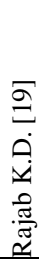 \\
\hline Motivation & & & 1 & 1 & 1 & & 1 & & 1 & & \\
\hline Attendance & 1 & & 1 & 1 & 1 & & 1 & & 1 & & 1 \\
\hline $\begin{array}{l}\text { Preparation } \\
\text { before class }\end{array}$ & 1 & & & 1 & & & & & & & \\
\hline Positivity & 1 & & & & 1 & 1 & 1 & & & 1 & \\
\hline $\begin{array}{l}\text { Adjusting to } \\
\text { new mediums }\end{array}$ & 1 & & 1 & 1 & 1 & & & 1 & & & \\
\hline $\begin{array}{l}\text { Communication } \\
\text { issues }\end{array}$ & 1 & & 1 & 1 & & & & 1 & 1 & & 1 \\
\hline $\begin{array}{l}\text { Student } \\
\text { development }\end{array}$ & 1 & 1 & & & & 1 & & & & & \\
\hline $\begin{array}{l}\text { Student } \\
\text { experience }\end{array}$ & & & 1 & & & & & 1 & & & \\
\hline Grades & 1 & 1 & & & & & & 1 & 1 & 1 & 1 \\
\hline Satisfaction & & & & & 1 & 1 & & & & 1 & \\
\hline Workload & & & & 1 & & 1 & & & & & 1 \\
\hline $\begin{array}{l}\text { Inter-student } \\
\text { relations }\end{array}$ & 1 & 1 & & 1 & & 1 & 1 & 1 & 1 & & \\
\hline Groupwork & & & & 1 & & 1 & & & & & 1 \\
\hline Isolation & & & 1 & 1 & & & & & 1 & & \\
\hline
\end{tabular}

\section{A. Student interaction with the communitiy}

Each case study compares these interactions with traditional face-to-face courses. Overall, interactions with a digital community generally showed a higher level of motivation, attention and engagement for students [13]. Students involved with interactive environments found learning outcomes, learning experience and overall structure were clearer than in traditional class [17]. When used in combination with face-to-face learning, higher levels of attendance were reported [9] and it led to advanced levels of preparation before classes [17]. An additional benefit for instructors, was that the most challenging concepts were the highest discussed points within the community [9].

Morillas et al found that there was a different level of positivity shown towards a given technology based on the course offered [13]. This was evident when comparing the student experience of different disciplines when given the same technologies to use. Students also need time to adjust to any major shift from traditional learning practices [17].

Personal student issues also come into play when interacting with in a new community. Weaker communication skills showed an increase in the difficulty to immerse themselves in some communities [11]. This could be the result of a reported lower level of content dissemination and guidance from lectures in digital communities. In fact, many students found the traditional lectures were more effective at covering a wide spectrum of academic content [17]. Rambocas et al recommended that the reasonability was on the instructors to make sure that new methods are explained effectively to students and their benefits are clearly demonstrated [17].

\section{B. Interaction $v s$ grades}

Conde et al used a system that rewarded higher participation with higher grades without penalization for low participation [9]. In their study they had an overwhelmingly positive $72.8 \%$ relationship of higher interaction levels of student achieved better grades. Gewerc et al may have found limited evidence of a positive relationship but concluded that the students with the lowest levels of participation often corresponded to the students with the lowest marks [11]. In contrast, Cheng et al found that while supplementary benefits were seen in the experimental group, there was no difference in the grades achieved [10]. This is supported by Rambocas et al who found no statistical difference in student performance [17]. Another measure that was used was the rate of students passing the course. When determining this, Rajab K.D. [19] and Encalada [16] both found no significant statistical difference. On the other hand, Rambocas et al found that the student development was significantly higher in the technology enabled classes [17] and there was a higher interest in completing courses using digital communities [18].

\section{Student experiences}

The numerous case studies evaluated in this paper demonstrate clear evidence for the benefit on the student experience. Students from Rambocas et al's study found the experience novel, enjoyed the community like environment and the opportunity to learn from classmates [17]. This is referring to the additional learning vector of another student in the course not just the lecturer. Higher levels of satisfaction [19] and interest [18] were also reported. 
Students of Warin et al's experimental class found the level of learning satisfaction was high but regretted the cost of a increased workload [14]. The students found that more effort was required to achieve the same results of traditional classes. Workload increases also put stress on inter-student relations in group work as concerns were raised of the performance of work by other team members [14]. Individual apprehensions also included a feeling of isolation brought on by a fear of public speaking and an alienation within the community [17]. This refers to the intimidating process of interacting with fellow students in a significantly more social way than is normally expected. Some students did not embrace the responsibility of constructing their own learning paths and were confused when presented with "so many different views on a single topic" [17].

\section{DISCUSSION}

The collected case studies provided compelling insight into the effect of digital communities on the grades achieved by the students. When compared with industry, companies use knowledge management technologies to gain a competitive edge over the competition [20]. The individual employee's benefits are measured by personal achievements such as monetary awards, promotion or social recognition. A common issue concerning knowledge management technologies is the balance of effort and reward. From the education side, increased work load was a regrettable cost when compared to the grades achieved [14]. Industry evidence indicated that the rewards received were not proportional to their perceived contribution to a digital community. This is further exemplified by feelings of underappreciation for their efforts and how their rewards did not meet their expectation [21].

This issue is exacerbated as employees found that benefits of monetary awards, promotion or social recognition were seldom received [21]. This lack of difference in the benefits received for the individual can be seen in the comparison between traditional courses and those using digital communities [16, 19]. Immediate benefits, either through financial or higher grades, are rarely documented when using these forms of technologies. On the other hand, student and professional development are often rated significantly higher when using these technologies [10, $17,21]$. This implies a positive impact of these technologies but the perceived benefits are sometimes lacking for the individual.

Beyond the academic performance and interaction with digital communities, it is important to study the student experience of using these new technologies. This is paralleled in industry as accompanying factors are often not considered when implementing new strategies [22]. It is important to select the appropriate technology for the right course [17]. Although an unbalanced approach with a focus on technology over personal issues, has led to many failures and unsuccessful implementations of digital communities
[23].This issue also leads to inter-student tensions as they were concerned about their contributions compared to the performance of their group members [14]. This is a common issue in industry as a feeling of loss of personal power and job security builds mistrust in the work place [24-26]. This is before you consider individual anxieties that are rooted in a feeling of isolation brought on by a fear of public speaking and an alienation within the community [17]. A step to counter this is measuring the popularity of discussed topics, as Conde et al found the most discussed topics were rated the most difficult by students [9].

\section{CONCLUSION}

In summary, by using education case studies that utilized technology for inter-student knowledge sharing, we have found a number of factors that impact the learning process. These factors were grouped into three areas. The first being how a student interacted with the community itself, which was measured in attendance, interaction and time. The second was the comparison of interaction and the effect this had on grades; this gave conflicting evidence to a positive correlation. The third group of factors was the student experience of the community. This focused on how a student rated the interaction and if they perceived any benefit of the community. All the factors outlined in this paper highlight the polarizing nature of using a technology-enabled community. The benefits are seen but the negative influencing factors still need to be addressed in each case study.

This paper is limited by the number of case studies collected and the differences in technologies used. Broadening the search parameters would allow for more confidence in the issues collected. Reliability could have been increased in the comparison of issues by providing a summary of case studies from the knowledge management literature. In that scenario, groups of case studies could have been compared directly, instead of using a wider collection of sources. This research presented in this paper could easily be expanded to include longitudinal case studies in the education sector by focusing on the recent developments in knowledge management and applying them to student communities.

In conclusion, this research highlighted the supporting influence knowledge management literature can have on the education industry. This was achieved by collecting common issues from various case studies and comparing them to existing knowledge management literature. Expanding this research has the potential to greatly benefit technology driven inter-student learning.

\section{ACKNOWLEDGEMENTS}

This research has been conducted with the support of the Australian Government Research Training Program Scholarship, ARC Discovery Project DP180101051, UOW Matching Scholarship 2018. 


\section{REFERENCES}

[1] A. Zaldivar, C. Tripp, J. A. Aguilar, J. E. Tovar, and C. E. Anguiano, "Using Mobile Technologies to Support Learning in Computer Science Students," IEEE Latin America Transactions, vol. 13, no. 1, pp. 377-382, 2015.

[2] X. L. Zheng, C. C. Chen, J. L. Hung, W. He, F. X. Hong, and Z. Lin, "A Hybrid Trust-Based Recommender System for Online Communities of Practice," IEEE Transactions on Learning Technologies, vol. 8, no. 4, pp. 345-356, 2015.

[3] Y. Cleary, "Community of Practice and Professionalization Perspectives on Technical Communication in Ireland," IEEE Transactions on Professional Communication, vol. 59, no. 2, pp. 126139, 2016.

[4] W. M. Al-Rahmi et al., "Use of E-Learning by University Students in Malaysian Higher Educational Institutions: A Case in Universiti Teknologi Malaysia," IEEE Access, vol. 6, pp. 14268-14276, 2018.

[5] L. Zetterqvist, "Applied problems and use of technology in an aligned way in basic courses in probability and statistics for engineering students; a way to enhance understanding and increase motivation," Teaching Mathematics and Its Applications: International Journal of the IMA, vol. 36, no. 2, pp. 108-122, 2017.

[6] V. R. Lee, J. R. Drake, and J. L. Thayne, "Appropriating Quantified Self Technologies to Support Elementary Statistical Teaching and Learning," IEEE Transactions on Learning Technologies, vol. 9, no. 4, pp. 354-365, 2016.

[7] T. David, D. David, and S. Palminder, "Towards a Methodology for Developing Evidence-Informed Management Knowledge by Means of Systematic Review," British Journal of Management, vol. 14, no. 3, pp. 207-222, 2003.

[8] T. Jones and D. Evans, "Conducting a systematic review," Australian Critical Care, vol. 13, no. 2, pp. 66-71, 2000/05/01/2000.

[9] M. A. Conde, F. J. Garcia-Penalvo, D.-A. Gomez-Aguilar, and R. Theron, "Exploring Software Engineering Subjects by Using Visual Learning Analytics Techniques," IEEE Revista Iberoamericana de Tecnologias del Aprendizaje, vol. 10, no. 4, pp. 242-252, 2015.

[10] P.-H. Cheng, Y.-T. C. Yang, S.-H. G. Chang, and F.-R. R. Kuo, "5E Mobile Inquiry Learning Approach for Enhancing Learning Motivation and Scientific Inquiry Ability of University Students," IEEE Transactions on Education, vol. 59, no. 2, pp. 147-153, 2016.

[11] A. Gewerc, A. Rodriguez-Groba, and E. Martinez-Pineiro, "Academic Social Networks and Learning Analytics to Explore Self-Regulated Learning: a Case Study," IEEE Revista Iberoamericana de Tecnologias del Aprendizaje, vol. 11, no. 3, pp. 159-166, 2016.

[12] M. J. W. Lee, S. Nikolic, P. J. Vial, C. Ritz, W. Li, and T. Goldfinch, "Enhancing Project-Based Learning Through Student and Industry
Engagement in a Video-Augmented 3-D Virtual Trade Fair," IEEE Transactions on Education, vol. 59, no. 4, pp. 290-298, 2016.

[13] C. Morillas Barrio, M. Munoz-Organero, and J. Sanchez Soriano, "Can Gamification Improve the Benefits of Student Response Systems in Learning? An Experimental Study," IEEE Transactions on Emerging Topics in Computing, vol. 4, no. 3, pp. 429-438, 2016.

[14] B. Warin, O. Talbi, C. Kolski, and F. Hoogstoel, "Multi-Role Project (MRP): A New Project-Based Learning Method for STEM," IEEE Transactions on Education, vol. 59, no. 2, pp. 137-146, 2016.

[15] J. Cruz-Benito, O. Borras-Gene, F. J. Garcia-Penalvo, A. F. Blanco, and R. Theron, "Learning Communities in Social Networks and Their Relationship With the MOOCs," IEEE Revista Iberoamericana de Tecnologias del Aprendizaje, vol. 12, no. 1, pp. 24-36, 2017.

[16] W. L. Encalada and J. L. C. Sequera, "Social Cloud for Information Technology Skills: An Experience With Universities in Ecuador," IEEE Revista Iberoamericana de Tecnologias del Aprendizaje, vol. 12, no. 2, pp. 76-85, 2017.

[17] M. Rambocas and M. K. S. Sastry, "Teaching Business Management to Engineers: The Impact of Interactive Lectures," IEEE Transactions on Education, vol. 60, no. 3, pp. 212-220, 2017.

[18] J. Rodriguez, I. Esparragoza, J. R. Ocampo, and R. Vigano, "Study of Motivation of Engineering Students on Multinational Design Projects," IEEE Revista Iberoamericana de Tecnologias del Aprendizaje, vol. 12, no. 4, pp. 218-226, 2017.

[19] K. D. Rajab, "The Effectiveness and Potential of E-Learning in War Zones: An Empirical Comparison of Face-to-Face and Online Education in Saudi Arabia," IEEE Access, vol. 6, pp. 6783-6794, 2018.

[20] T. A. Stewart, "Intellectual Capital: The new wealth of organizations," New York: Currency Doublebay, 1997.

[21] B. M. Han and V. S. Anantatmula, "Knowledge Management in IT Organizations From Employee's Perspective," Proceedings of the 39th Haawaii International Conference on System Sciences, 2006.

[22] B. Reimus, "The IT system that couldn't deliver," Harvard Business Review, vol. 75, no. 3, pp. 22-24, May/June 1997.

[23] T. Davenport, "Enterprise Systems," Harvard Business Review no. 121, July-August 1998 .

[24] C. G. O'Dell, C.J., "If Only We Knew What We Know: Indentification and Transfer of Internal Best Practice," American Productivity \& Quality Center, vol. Best Practices White Paper, 1998.

[25] K. E. Sveiby, "The New Organizational Wealth, Managing and Measuring Knowledge-Based Assets," San Francisco, CA: BerretKoehler Publishers Inc, 1997.

[26] K. M. Wiig, "Supporting Knowledge Management: A Selection of Methods and Techniques.," Expert Systems with Applications, vol. 13, no. 1, pp. 15-27, 1997. 